\title{
Pelatihan Penerapan Program Statistical Product for Service Solution (SPSS) untuk Data Keolahragaan
}

\author{
Saharuddin Ita ${ }^{1}$, Ibrahim ${ }^{2}$, MFP Putra*2 \\ ${ }^{\text {I}}$ Prodi Magister Pendidikan Olahraga, Program Pascasarjana, Universitas Cenderawasih, Jayapura, Indonesia; \\ ${ }^{2}$ Prodi Ilmu Keolahragaan, Fakultas Ilmu Keolahragaan, Universitas Cenderawasih, Jayapura, Indonesia
}

\section{Article history}

Received: 06 September 2019

Revised: 02 Oktober 2019

Accepted: 28 November 2019

*Corresponding Author:

\section{MFP Putra}

Prodi Ilmu Keolahragaan

Fakultas Ilmu Keolahragaan

Universitas Cenderawasih,

Jayapura, Indonesia

Email: mifpputra@gmail.com

\begin{abstract}
The dedication activity is expected to make participants (1) understand well about the SPSS program, and (2) can use the SPSS program to analyze the sports data (training results) that have been conducted. The results of the activities are (1) most of the trainees only know the SPSS program, (2) only a small number of participants can install the SPSS program independently, (3) most trainees understand well about the history and function of the SPSS, (4) some large participants can do descriptive analysis, test data requirements, correlation, $t$ test (dependent and independent) independently, (5) only a small number of participants can do regression analysis and ANOVA.
\end{abstract}

Keywords: SPSS; data analysis; training; sport

Abtrak: Kegiatan pengabdian tersebut diharapkan dapat membuat peserta (1) memahami dengan baik tentang program SPSS, dan (2) dapat menggunakan program SPSS untuk menganalisis data keolahragaan (hasil latihan) yang sudah dilakukan. Hasil kegiatan adalah (1) sebagian besar peserta pelatihan ternyata baru mengetahui program SPSS, (2) hanya sebagian kecil peserta yang dapat menginstal program SPSS secara mandiri, (3) sebagian besar peserta pelatihan memahami dengan baik tentang sejarah dan fungsi SPSS, (4) sebagian besar peserta dapat melakukan analisis deskriptif, uji persyaratan data, korelasi, uji t (dependent dan indepent) secara mandiri, (4) hanya sebagian kecil peserta yang dapat melakukan analisis regresi dan anova

Kata Kunci: SPSS; analisis data; olahraga; pelatihan

\section{PENDAHULUAN}

Terbitnya Surat keputusan Menteri Pemuda dan Olahraga Nomor 0110 tahun 2014 tanggal 2 April 2014 yang menetapkan Provinsi Papua sebagai tuan rumah penyelengaraan Pekan Olahraga Nasional (PON) ke-XX tahun 2020 merupakan tonggak sejarah dalam olahraga Papua. Pasalnya, hal ini merupakan untuk pertama kalinya Provinsi Papua terpilih sebagai tuan rumah dalam even olahraga terbesar Indonesia. Oleh karena itu, tidak mengherankan bila masyarakat Papua menjadi sangat antusias menyambut datangnya PON XX tahun 2020.

Seperti yang acapkali disampaikan oleh Gubernur Papua dalam berbagai kesempatan, bahwa Papua harus dapat sukses sebagai penyelengara dan sukses prestasi. Khusus untuk sukses prestasi, tidak lah semudah membalikkan telapak tangan karena banyak faktor yang berjalin-berkelindan di dalamnya. Hal ini tidak mengherankan karena atlet yang tampil di PON adalah para atlet tingkat 
nasional. Oleh karena itu, bukan hanya teknik dan taktik saja yang perlu mendapatkan perhatian, namun kemampuan fisik juga perlu diperhatikan. Malangnya, untuk meningkatkan kondisi fisik atlet tidaklah sesederhana yang dibayangkan.

Secara terminologi, kondisi fisik berarti keadaan fisik yang meliputi sebelum (kemampuan awal) maupun pada saat dan setelah mengalami suatu proses latihan. Bompa (2009) menyebutkan yang dimaksud dengan kondisi fisik adalah kemampuan yang meliputi kekuatan (strenght), kecepatan (speed), daya tahan (endurance), kelentukan (flexibility) dan koordinasi. Mengetahui data tentang kondisi kemampuan fisik atlet amatlah penting karena ini yang akan dijadikan dasar dalam penyusunan periodisasi latihan.

Namun, fakta di lapangan menunjukkan bahwa masyarakat (pengurus cabang olahraga) masih kebingungan melakukan analisis data hasil latihan yang diperoleh. Padahal, analisis data tersebut sangat penting untuk mengetahui bagaimana progress latihan atlet, bagaimana hubungan antar variabel fisik yang satu dengan lainnya, bagaimana kontribusi kemampuan fisik satu dengan yang lainnya. Berdasarkan pengalaman penulis, data-data hasil latihan tersebut berhenti di atas meja dan tidak ditindaklanjuti dalam program latihan yang dirancang.

Berikutnya, hal yang sama ditemukan di lapangan adalah mahasiswa olahraga jenjang S1 dan S2 olahraga kerap kebingungan bila dihadapkan pada analisis data keolahragaan yang diperoleh. Padahal, mereka harus mengolah data tersebut kemudian menafsirkanya dan melaporkannya. Itu sebabnya terdapat mahasiswa yang lulusnya terlambat dari sebagaimana mestinya yang disebabkan karena belum selesai menganalisis dan melaporakan data penelitian keolahragaannya. Data tersebut penulis peroleh dari hasil pengamatan dan wawancara dengan para mahasiswa. Umumnya, ketika ditanya tentang progress penelitiannya mahasiswa akan menjawab masih kebingungan dengan cara anlisis data penelitian dan menafsirkannya.

Atas dasar uraian dan kondisi di lapangan maka kegiatan tersebut akan berusaha untuk mengenalkan serta meningkatkan keterampilan masyarakat (pengurus cabor dan mahasiswa olahraga S1 sertaa S2) dalam mengunakan program statistical product for service solution (SPSS). Pertanyaannya kemudian, apakah program SPSS dapat diaplikasikan dalam konteks data keolahragaan untuk mendukung prestasi atlet? Iya, sangat dapat diaplikasikan. Seperti namanya, program tersebut sebenarnya digunakan untuk data-data ilmu sosial. Data keolahragaan seperti tinggi badan, berat badan, kecepatan, kekuatan, keseimbangan, koordinasis, kelincahan, daya tahan dan sebagainya dapat dianalisis oleh program tersebut.

Ketika pengurus cabor (pelatih) dapat menggunakan program SPSS dengan baik maka hal ini akan sangat mendukung rancangan latihan yang dilakukan. Program latihan yang dilakukan akan didasarkan pada hasil analisis perkembangan data latihan yang dijalankan oleh atlet, sehingga besar kemungkinan latihan yang dilakukan akan berbasis data yang riil serta ilmiah. Dengan cara yang demikian maka tidak mustahil kualitas latihan akan meningkat yang pada gilirannya prestasi atlet Papua juga akan naik serta dapat meraih kesuksesan dalam PON XX nanti.

Berdasarkan uraian di atas maka kegiatan pengabdian tersebut memiliki dua tujuan sebagai berikut: setelah mengikuti pelatihan penerapan program SPSS untuk data keolahragaan, peserta pelatihan diharapkan mampu (1) memahami dengan baik tentang program SPSS, dan (2) menggunakan program SPSS untuk menganalisis data keolahragaan (hasil latihan) yang sudah dilakukan. 


\section{METODE}

Kegiatan pelatihan penerapan program Statistical Product and Service Solutions (SPSS) untuk data keolahragaan akan dikakukan dengan menggunakan metode presentasi yang mengacu pada karya Joyce \& Weil (2003) serta Arends $(2007 ; 2009)$. Metode presentasi ini memiliki tiga tahap kegiatan. Tahap 1 adalah presentasi advance organizer, tahap 2 adalah presentasi tugas pembelajaran atau materi pelatihan, dan tahap 3 adalah penguatan pengolahan kognitif. Tahap terakhir ini menguji hubungan materi pelatihan dengan gagasan-gagasan yang ada untuk menghasilkan proses pembelajaran aktif. Setiap tahap dan perilaku pengajar nampak seperti pada tabel 1 di bawah ini:

Tabel 1. Sintaks Metode Presentasi (Diadaptasi dari Joyce \& Weil, 2003; Arends, 2007; 2009)

\begin{tabular}{l|l}
\hline Tahap & Perilaku Pembelajar \\
\hline Tahap 1: mempresentasikan & $\begin{array}{l}\text { Fasilitator mempresentasikan tujuan } \\
\text { pembelajaran atau pelatihan, menyajikan } \\
\text { advance organizer } \\
\text { peserta dalam pelatihan (memotivasi) }\end{array}$ \\
\hline $\begin{array}{l}\text { Tahap 2: presentasi materi } \\
\text { pembelajaran atau pelatihan } \\
\text { dan tugas pembelajaran }\end{array}$ & $\begin{array}{l}\text { Fasilitator mempresentasikan materi } \\
\text { pelatihannya, dengan memperhatikan urutan } \\
\text { logisnya dan maknanya bagi peserta. Setelah } \\
\text { itu, fasilitator mempresentasikan tugas yang } \\
\text { harus diselesaikan oleh peserta pelatihan }\end{array}$ \\
\hline Tahap 3: penguatan & $\begin{array}{l}\text { Fasilitator melontarkan berbagai petanyaan dan } \\
\text { memperkuat, membangkitkan respon peserta } \\
\text { terhadap presentasinya }\end{array}$ \\
\hline
\end{tabular}

Dari sintaks pada tabel $1 \mathrm{di}$ atas dapat dikatakan metode presentasi yang dilakukan dalam penelitian ini berbeda dengan metode ceramah atau metode konvensional pada umumnya. Menurut Arends (2007) ada tiga ide komplementar yang dipersatukan untuk memberikan dukungan teoritis dan empiris bagi model pengajaran presentasi. Yang petama, konsep structure of knowledge, yang kedua, meaningfull verbal information, dan yang ketiga, ide-ide dari congnitive psychology tentang bagaimana sistem ingatan manusia bekerja dan bagaimana pengetahuan dipresentasikan dan diperoleh.

Dalam model presentasi yang perlu diperhatikan adalah adanya tahap advance organizer. Advance organizer diciptakan oleh salah satu pakar psikologi pendidikan yaitu David Ausubel. Saat para teoritikus pendidikan dan kritikus sosial tengah menantang keabsahan metode-metode yang berpusat pada guru (teacher centered) seperti presentasi, Ausubel tanpa rasa ragu tetap berpihak pada strategi penguasaan materi akademik melalui presentasi (Joyce \& Weil, 2003). Menurut Ausubel advance organizer berfungsi melukiskan dengan jelas, tepat, dan eksplisit persamaan dan perbedaan prinsip antara ide-ide yang ada dalam sebuah hal yang sedang dipelajari (Arends, 2007; 2009). Konsepsi yang melandasi Ausubel adalah untuk belajar informasi baru diperlukan adanya struktur kongnitif (Degeng, 1997). Dalam tahap advance organizer inilah berguna sebagai perancah (scaffolding) untuk pebelajar.

sebagai berikut:

Adapun materi pelatihan yang diberikan dalam kegiatan yang diusulkan tersebut adalah

Sejarah program SPSS

Tujuan dan manfaat menggunakan SPSS untuk mengolah data keolahragaan

Jenis atau macam data keloahragaan

Cara menginstal program SPSS versi 23

Pengenalan tool atau menu yang ada di SPSS

Analisis deskriptif data keolahragaan 
Analisis uji persyaratan data

Analisis uji beda (uji t) data keolahragaan

Analisis uji korelasi sederhana data keolahragaan

Analisis regresi sederhana dan ganda

Analisis varian (Anava)

\section{HASIL DAN PEMBAHASAN}

Masalah seperti data hasil latihan atlet yang tidak dianalisis dengan baik oleh pengurus cabor; mahasiswa olahraga yang kerap kebingungan ketika dihadapkan dengan tugas melakukan analisis dan menafsirkan datanya telah dipecahkan dalam kegiatan pelatihan penerapan analisis data menggunakan program SPSS. Untuk mengikuti kegiatan sejenis di luar maka biaya yang harus dikeluarkan tidaklah sedikit. Berdasarkan pantauan penulis, untuk mengikuti pelatihan pelatih fisik tingkat dasar, biaya pendaftaran yang harus dikeluarkan berkisar antara 3-5 juta. Ini belum termasuk biaya perjalanan yang harus ditanggung oleh peserta sendiri. Biaya yang sama juga akan ditemui untuk mengikuti workshop SPSS, yaitu berkisar 2-3 juta per paket pembelajaran.

Kegiatan pengabdian tersebut diikuti sebanyak 22 peserta yang dilakukan selama empat jam. Pelaksanaan kegiatan pengabdian terbagi kedalam tiga tahapan. Tahap pertama, penulis mempresentasikan tujuan pembelajaran atau pelatihan, menyajikan advance organizer, dan mendorong kesadaran peserta dalam pelatihan (memotivasi). Tahap kedua, mempresentasikan materi pelatihannya, dengan memperhatikan urutan logisnya dan maknanya bagi peserta. Setelah itu, fasilitator mempresentasikan tugas yang harus diselesaikan oleh peserta pelatihan. Tahap ketiga, melontarkan berbagai petanyaan dan memperkuat, membangkitkan respon peserta terhadap presentasinya. Dokumentasi kegiatan seperti gambar berikut ini:
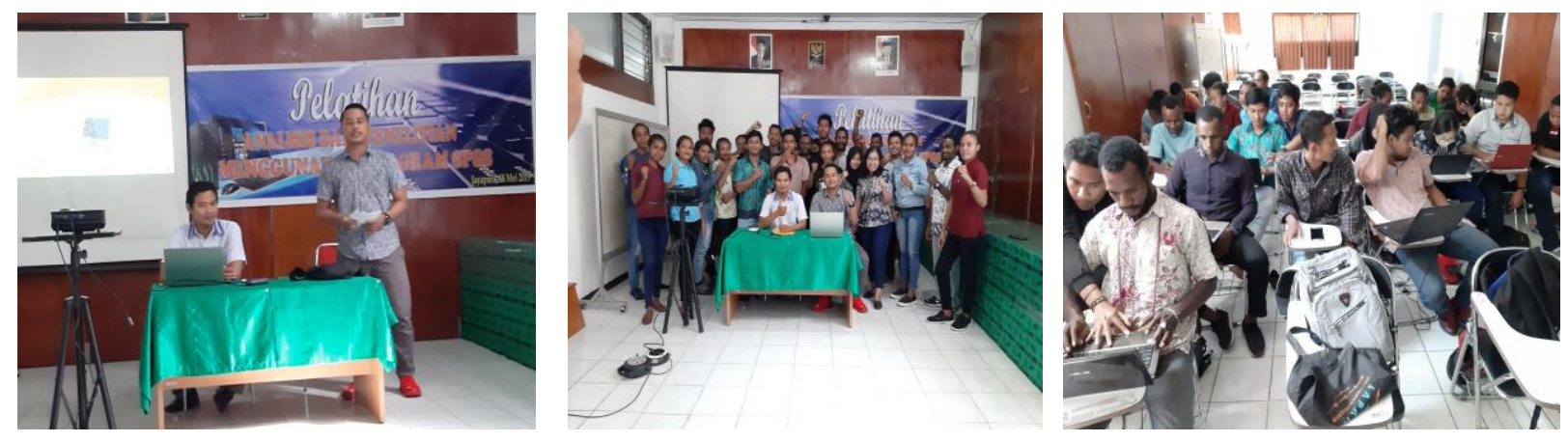

Gambar 1 Rangkaian proses kegiatan pelatihan

Pada tahap ketiga, beberapa pertanyaan diajukan oleh penulis untuk mengetahui tingkat pemahaman dari peserta pelatihan (lihat gambar 2). Untuk pertanyaan "apakah anda sudah mengetahui tantang SPSS sebelumnya?" para peserta menjawab seperti yang tersaji pada gambar 2. Dari gambar 2 tersebut tampak bahwa sebagain besar peserta (19 orang) belum mengetahui tentang program SPSS. Hanya sebagian kecil saja peserta yang sudah pernah mendegar tentang program SPSS, yaitu sebanyak 3 orang.

Pertanyaan lainnya yang dilontarkan adalah "Apakah anda memahami sejarah bagaimana SPSS diciptakan?" terhadap pertanyaan tersebut, para peserta memberikan jawaban yang beragam namun kalau dikelompokan akan mengerujut pada tiga hal seperti yang ada di gambar 2 atas bagian kiri. Dari gambar tersebut tampak bahwa peserta kegiatan pelatihan sebagian besar ( 15 orang) mampu memahami sejarah bagaimana program SPSS diciptakan. Terdapat 5 orang yang jawabannya kurang begitu sesuai dan hanya 2 orang saja yang belum paham tentang sejarah program SPSS tercipta. 

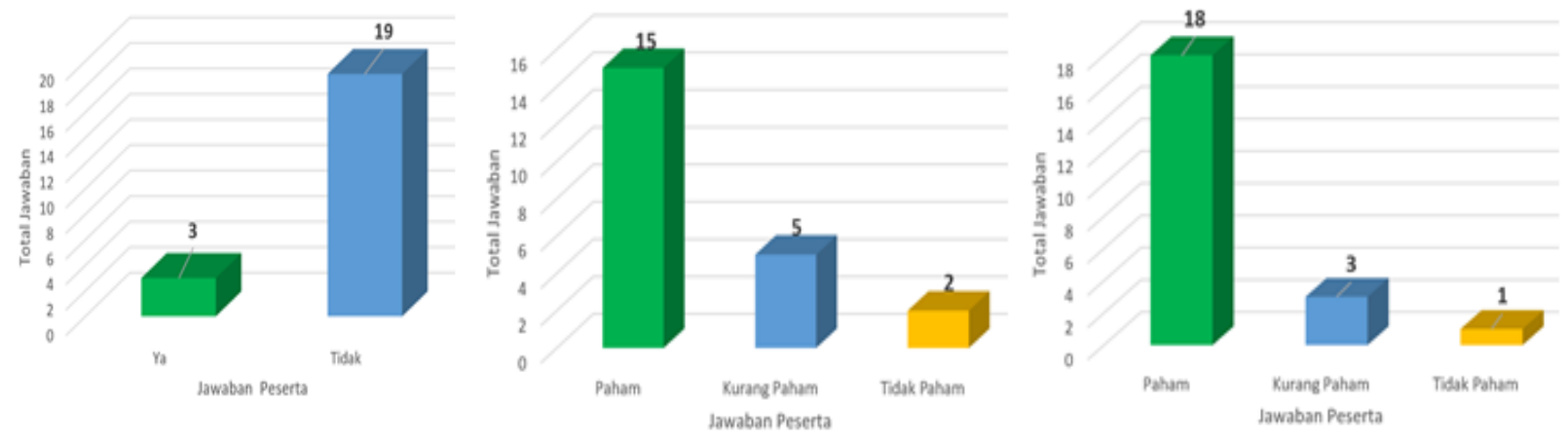

Gambar 2 Pemahaman peserta terkait materi kegiatan pelatihan

Pertannyaan berikutnya yang diajukan adalah "Apakah anda memahami fungsi program SPSS?". Terhadap pertanyaan tersebut, para peserta memberikan jawaban yang beragam namun kalau dikelompokan akan mengerujut pada tiga hal seperti yang ada di gambar 2 bagian kanan. Dari gambar 2 tersebut tampak bahwa peserta kegiatan pelatihan sebagian besar (18 orang) mampu memahami fungsi program SPSS dengan baik. Terdapat 3 orang yang jawabannya kurang begitu sesuai dan hanya 1 orang saja yang belum paham tentang fungsi program SPSS.

Dalam kegiatan pengabdian tersebut tampak sebagian besar peserta mampu menjalankan analisis secara mandiri ketika diberikan tugas untuk menganalisis data keolahragaan (lihat gambar 1). Umumnya, peserta dapat melakukan analisis secara mandiri ketika diberikan tugas untuk menganalisis deskriptif, uji persyaratan data, korelasi, uji t (dependent dan indepent). Fasilitator tidak menemukan ada peserta yang belum bisa mengoperasikan program SPSS ketika diminta untuk menganalisis data yang ada.

Akan tetapi hasil yang berbeda didapat ketika masuk pada tugas analisis regresi dan anova. Para peserta merasa masih binggung dalam melakukan analisis dengan SPSS. Hal ini terjadi karena peserta merasa bahwa analisis regresi dan anova lebih sukar dan kompleks bila dibandingkan dengan analisis yang sebelumnya. Itu sebabnya, fasilitator harus membimbing sebagian besar peserta pelatihan. Meskipun begitu, kegiatan pengabdian yang dilakukan tersebut tergolong berhasil karena peserta terlihat sangat antusias dan serius mengikuti kegiatan dari awal hingga akhir kegiatan.

\section{KESIMPULAN DAN SARAN}

Berdasarkan hasil kegiatan pengabdian yang dilakukan maka dapat disimpulkan sebagai berikut: pertama, peserta pelatihan, terutama mahasiswa Prodi S1, ternyata baru mengetahui program SPSS dari pelatihan yang dilakukan; kedua, hanya sebagian kecil peserta yang dapat menginstal program SPSS secara mandiri. Hal ini dikarenakan terdapat kendala dengan laptop yang dibawa oleh peserta, misalnya, ruang penyimpanan laptop yang sudah hampir penuh sehingga tidak dapat lagi diinstal dengan SPSS; ketiga, sebagian besar peserta pelatihan memahami dengan baik tentang sejarah dan fungsi SPSS; keempat, sebagian besar peserta dapat melakukan analisis deskriptif, uji persyaratan data, korelasi, uji t (dependent dan indepent) secara mandiri; kelima, hanya sebagian kecil peserta yang dapat melakukan analisis regresi dan anova;

Saran yang dapat diajukan bertalian dengan hasil pengabdian tersebut, yaitu pelatihan sejenis lebih rutin dilakukan dan dengan melibatkan peserta yang lebih luas serta dilakukan di laboratorium komputer agar permasalahan terkait dengan masalah instalasi SPSS tidak muncul lagi. 


\section{Ucapan Terima Kasih}

Penulis mengucapkan terima kasih kepada LPPM UNCEN yang telah memberi dukungan financial terhadap pengabdian ini.

\section{DAFTAR PUSTAKA}

Arends, R.I. 2007. Learning to Teach $7^{\text {th }}$. New York: McGraw Hill Companies, Inc. 2007. Learning to Teach $9^{\text {th }}$. New York: McGraw Hill Companies, Inc

Bompa, T.O. 2009. Theory and methodology of training $5^{\text {th }}$. Champaign: Kendal/Hut Publishing Company

Degeng, I.N.S. 1997. Startegi Pembelajaran Mengorganisasikan Isi Dengan Model Elaborasi. Malang: IKIP Malang

Ho, Robert. 2006. Handbook of univariate and multivariate data analysis and interpretation with SPSS. Boca Raton, FL: Chapman \& Hall/CRC

Joyce, B., \& Weil, M. 2003. Models of Teaching $5^{\text {th }}$. New Delhi: Prentice-Hall, Inc.

Putra, M.F.P. 2016. Petanque olahraga potensial di Papua. Cenderawasih Pos 14 Oktober halaman 6. Riadi, E. 2016. Statistika Penelitian. Yogyakarta: Andi Offset. 